\title{
Kansen van een crisis
}

Door Wim Burggraaff \& Judith Logger

Samenwerken en samensturen is doorgaans een complex proces, maar lijkt in tijden van crisis gemakkelijker te gaan. Vooral in de eerste maanden van de coronapandemie nam de onderlinge solidariteit tussen burgers toe, zo illustreren diverse sociale initiatieven die van de grond kwamen om mensen in de knel te helpen. Veel daarvan speelden zich af rond buurthuizen. Hoe kwam samenwerking en besluitvorming daarbij tot stand? En hoe duurzaam zijn dergelijke initiatieven?

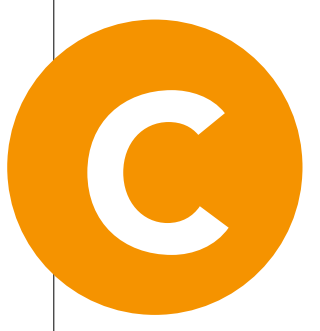
een relatief klein sociaal netwerk. Daarnaast ontstaan ook 'nieuwe' kwetsbare groepen: mensen met een tijdelijke baan en zzp'ers, onder wie veel jongeren. Maar onderzoek wijst ook uit dat covid-19 niet alleen negatieve gevolgen heeft. Het aandeel mensen dat aangeeft (meer) hulp te bieden aan buren is sinds april 2020 toegenomen. In steden ontstonden allerlei maatschappelijke initiatieven, waarbij mensen uiteenlopende vormen van hulp gaven aan anderen. Zo werden alleen al in Rotterdam 91 maatschappelijke ‘corona-initiatieven' geïnventariseerd. Volgens Boonstra \& Claessens (2021) vergroten die de maatschappelijke veerkracht: het vermogen van bewoners, lokale overheid en professionals om samen op een positieve manier met tegenslag om te gaan. Dergelijke initiatieven ontstaan bovendien in een kort tijdsbestek, waarmee ze een snel antwoord zijn op een urgente kwestie en bijdragen aan meer onderlinge verbondenheid in wijken.

Buurthuizen werden belemmerd doordat zij tijdens de eerste lockdown hun deuren moesten sluiten.
Ze konden maar een beperkt aantal activiteiten opstarten en/of voortzetten, vaak voor specifieke doelgroepen. Professionals, vrijwilligers en bewoners zochten niettemin naar creatieve manieren om ook contact te houden met andere mensen uit de wijk.

\section{Maaltijden}

Rondom huis van de wijk 't Steiger in Rotterdam ontstonden tijdens de eerste lockdown verschillende initiatieven om de meest kwetsbare bewoners van de wijk te ondersteunen en de saamhorigheid in de wijk te vergroten. In korte tijd werd onder andere vanuit 't Steiger een systeem opgezet om bij zo'n twee- tot driehonderd kwetsbare ouderen
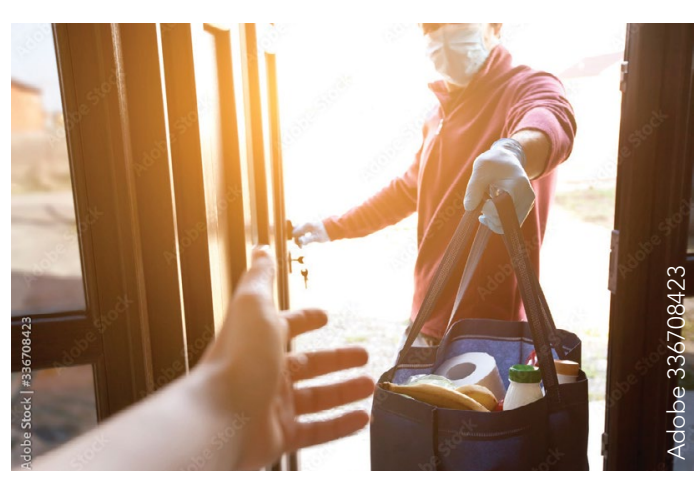


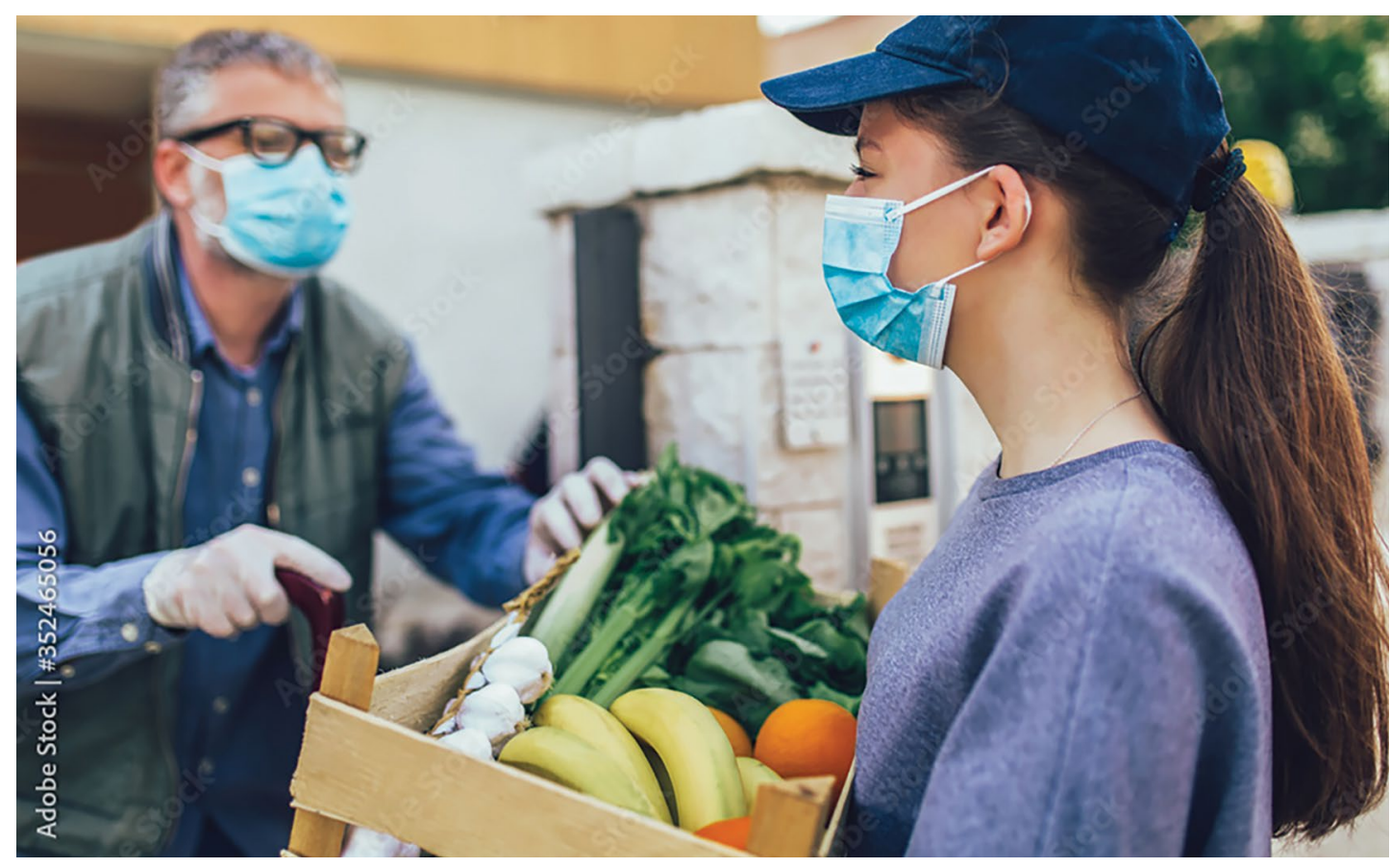

maaltijden, boodschappen en, tijdens de feestdagen, iets lekkers of een bloemetje te brengen. Opvallend zijn de contacten die daarbij ontstonden tussen (groepen) bewoners die in de gegentrificeerde stadswijk eerder weinig met elkaar in aanraking kwamen. Het huis van de wijk had voorafgaand aan de pandemie een beperkte groep vaste bezoekers en vrijwilligers: vrijwel allemaal oorspronkelijke bewoners die zich het huis als het ware toegeëigend hadden, omdat ze het zagen als het laatste authentieke stukje van hun wijk. In een snel en sterk veranderende buurt was dit de laatste plek waar zij zich thuis voelden en waar bovendien een kopje koffie en een biertje voor hen nog betaalbaar waren. Het lukte nauwelijks om ook nieuwe(re) bewoners te betrekken bij activiteiten in of rondom het huis van de wijk, laat staan om samen met hen iets te organiseren. Maar tijdens de corona-pandemie lukte dit wel. Vaste vrijwilligers uit de oorspronkelijke bewonersgroep kookten, waarna nieuwere, meestal thuiswerkende volwassenen en jongeren uit de wijk de maaltijden rondbrachten bij oudere en vaak kwetsbare bewoners. Aangejaagd door de professionals uit het huis van de wijk ontstonden zo verbindingen die er eerder niet waren.

\section{Verbindende rol}

Ook een ander gezamenlijk initiatief vergrootte de saamhorigheid in de buurt. Een professional uit het huis van de wijk regelde in samenwerking met bewoners en andere organisaties uit de buurt dat tijdens de Dodenherdenking op 4 mei 2020 blazers op verschillende straathoeken in de wijk het taptoe-signaal speelden. Volgens de betrokken professionals leidde dit tot een gevoel van verbondenheid onder alle groepen bewoners en werd dit als dermate positief ervaren dat er een groter initiatief uit voortkwam. Daarbij zijn ook andere feest- en gedenkdagen betrokken, zoals keti koti en de ramadan. De betrokken professional is zelf bewoner van de wijk en bovendien bestuurslid van een stichting die onder andere tot doel heeft de saamhorigheid in de wijk te vergroten. De verbindende rol die hij heeft, is mogelijk van invloed geweest op het ontstaan en het succes van deze initiatieven.

\section{Kans}

In het Haagse buurthuis Mandelaplein zagen we hoe professionals tijdens de lockdown op allerlei manieren probeerden in contact te blijven met hun belangrijkste groepen deelnemers en wijkbewoners. Ze belden hen en stuurden kaartjes. Ook het buurt-preventieteam, het meest outreachend werkende onderdeel van de organisatie, hield een vinger aan de pols. De meivakantie 2020 viel in de eerste lockdown-periode. Daarom werden vakantieactiviteiten voor de jeugd in die weken online aangeboden. Elke dag was er op YouTube een livestream vanuit het buurthuis te volgen en deelnemende kinderen ontvingen thuis een tasje met werkmaterialen.

$\mathrm{Nu}$ het jeugdaanbod online verliep, kozen de organisatoren voor een breder bereik: niet alleen de eigen en vaste doelgroep, maar álle kinderen uit de wijk konden deelnemen. Buurthuisprofessionals stelden nieuwe coalities samen door potentiële partners - een andere welzijnsinstelling in de wijk, een sociaal on- 
dernemer, de bibliotheek en een museum - te vragen of ze mee wilden doen aan het online aanbod voor de jeugd en, zo ja, welke rol ze dan zagen voor zichzelf. Ook vroegen ze bij diverse fondsen middelen aan voor het project. Een en ander leidde tot nieuwe samenwerkingsverbanden, waarin het buurthuis een leidende rol had. 'Dit was een kans om een keer wat samen te doen,' zei een van de professionals erover. De samenwerking ontstond onder tijdsdruk en de betrokken professionals konden elkaar niet live spreken. Alle overleg verliep dus via videobellen, telefoon en WhatsApp. Het project ging van start met een brainstorm over mogelijke activiteiten. Daarnaast werden de dagdelen verdeeld. Elke partij was vervolgens zelf verantwoordelijk voor de verdere invulling van de activiteit.

\section{Nasleep}

De samensturing rond het online jeugdaanbod in dit Haagse buurthuis werd achteraf door betrokken partijen wisselend beoordeeld. Vóór de pandemie werkten de betrokken organisaties niet samen. Zelfs onderling afstemmen was lastig, omdat iedereen zich beperkte tot de eigen doelgroep. Terugkijkend geven de professionals van het buurthuis en die uit de andere welzijnsinstelling aan dat de tijdelijke coalitie hen goed is bevallen.

De samenwerking tussen de buurthuisprofessionals, de welzijnsinstelling en de sociaal ondernemer verliep minder goed. Dit kwam vooral naar voren toen de financiële afwikkeling van het project een lange nasleep kreeg. De sociaal ondernemer blikte met gemengde gevoelens terug op het project. Het was als relatief kleine partij lastig samenwerken geweest met de grotere instellingen, oordeelde hij. Hij kon logistieke wijzigingen in de aanpak minder makkelijk opvangen dan de andere partners en vond ook dat hij, vergeleken met hen, minder exposure kreeg.

\section{Nieuwe verbindingen}

Bovenstaande praktijkvoorbeelden uit Rotterdam en Den Haag laten zien dat er door de coronapandemie in het werkveld van buurthuizen nieuwe samenwerkingsverbanden en nieuwe methodieken ontstaan. De vraag is of deze nieuwe verbindingen en manieren van samenwerken duurzaam zijn. Het 4 mei-project in de Rotterdamse wijk lijkt, vanwege de positieve bijdrage ervan aan de verbondenheid in de wijk, een vervolg te krijgen. Maar tijdens de tweede lockdown bleek ook dat het animo onder bewoners en organisaties om mee te doen aan het koken en bezorgen van maaltijden was afgenomen. Het Haagse project leverde de stakeholders geen duurzaam model van samensturing op. Er was voor de duur van het project een duidelijk doel. Hoewel sommige deelnemers het proces 'rommelig' noemden, waren ieders rol en bijdrage duidelijk. Achteraf bleek ook dat er tussen de welzijnsinstellingen en de sociaal ondernemer veel verschil van inzicht was geweest over de invulling van het programma en ieders commitment. Rond de nieuwe initiatieven werd een vorm van communicatie opgezet, online vanwege de corona-maatregelen. Fondsen voorzagen in de benodigde financiële middelen en de gemeente was niet actief betrokken bij de hier geanalyseerde voorbeelden van samensturing. Het initiatief en leiderschap van de buurthuisprofessionals leidde in beide gevallen tot weliswaar tijdelijke, maar nieuwe verbindingen: in Rotterdam werkten groepen samen die voor de pandemie niet met elkaar in aanraking kwamen en in Den Haag ontstond samenwerking tussen organisaties die niet eerder een coalitie aangingen.

Al met al kunnen we concluderen dat duurzame samensturing in buurthuizen baat lijkt te hebben bij een projectmatige start, professionals die het initiatief nemen (zie in dit verband ook het artikel over faciliterend leiderschap, pg.17-19) en een transparante organisatie van de samenwerking, met voor iedereen een duidelijke rol.

Wim Burggraaff is als onderzoeker, docent en beleidsmaker actief met vraagstukken op het gebied van participatie.Ten tijde van het hier besproken onderzoek naar samensturlng bij buurthuis Mandelaplein was hij verbonden aan de Haagse Hogeschool, lectoraat Grootstedelijke Ontwikkelingen. Daarnaast gaf hij les bij de opleiding Social Work. Nu werkt hij als participatiespecialist bij de Rijksdienst voor Cultureel Erfgoed.

Judith Logger is cultureel antropoloog en docent-onderzoeker bij het lectoraat Dynamiek van de Stad van Hogeschool Inholland, Rotterdam. Zij werkte voor het lectoraat mee aan verschillende onderzoeken op het gebied van diversiteit en is momenteel betrokken bij onderzoek naar samensturing in huizen van de wijk en naar stadslabs. Ook geeft zij les aan de opleiding Social Work.

\section{Bronnen}

- Boonstra, B. \& Claessens, S. (2021). Maatschappelijke coalities in coronatijd: Van spontaan initiatief naar duurzaam samenwerkingsverband. Rotterdam: Erasmus School of Social and Behavioural Sciences \& Kenniswerkplaats Leefbare Wijken

- Engbersen, G., e.a. (2020). De Verdeelde Samenleving: De Maatschappelijke impact van COVID-19 in Amsterdam, Den Haag, Rotterdam \& Nederland. Rotterdam: Kenniswerkplaats Leefbare Wijken 